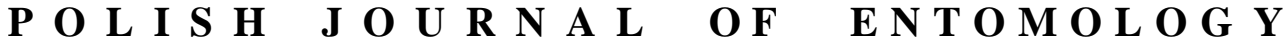

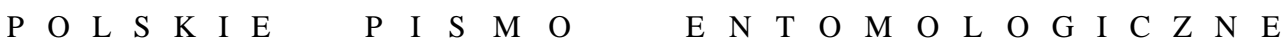

VOL. 87: 119-140

Lublin

30 June 2018

DOI: $10.2478 /$ pjen-2018-0009

\section{Efficacy of Piper guineense SCHUMACH. seed powder in the control of Callosobruchus maculatus (FABRICIUS, 1775) (Coleoptera: \\ Chrysomelidae: Bruchinae) and on the nutritional and organoleptic characteristics of stored cowpea Vigna unguiculata (L.) WALP.}

\author{
FRANK O. OJIAKO $^{1 *}$, ADEYINKA A. AdESIYUN ${ }^{2}$, GABRIEL O. IHEJIRIKA $^{1}$, \\ SUNDAY A. DIALOKE ${ }^{1}$ \\ ${ }^{1}$ Department of Crop Science and Technology, Federal University of Technology, Owerri, \\ Imo State, Nigeria \\ ${ }^{2}$ Department of Crop Protection, University of Ilorin, Ilorin, Nigeria
}

\begin{abstract}
Brown pepper (Piper guineense) seed powder, used for culinary and medicinal purposes, was evaluated in the laboratory with a conventional storage chemical, actellic $2 \%$ dust (Pirimiphos-methyl), as standard, to protect stored cowpea against the cowpea bruchid, Callosobruchus maculatus. Four rates of the seed powder were used $(2.5,5.0$ and $10.0 \mathrm{~g} / 100 \mathrm{~g}$ seed with a control, $0.0 \mathrm{~g}$ ) while actellic dust was applied at 1.0, 2.0, $3.0 \mathrm{~g} / 100 \mathrm{~g}$ seed and $0.0 \mathrm{~g} / 100$ $\mathrm{g}$ seed as control. Data on percentage mortality, oviposition, adult emergence and seed damage were collected over a six-month period. Weevil perforation indexes (WPI) were estimated with the seed damage data. All data were analysed for variance at $\mathrm{P} \leq 0.05$. Actellic dust at the lowest dose inflicted adult mortality $(90-100 \%)$ in the first $48 \mathrm{~h}$ after treatment and prevented oviposition ( 95 - 100\%) in the first five months of storage compared to the control. The highest rate of Piper guineense application caused mortality of up to $90.0 \%$ in $48 \mathrm{~h}$, reduced oviposition $(70-80 \%)$, decreased adult emergence (15.90 to 28.40 insects) as against the control (104.7 - 272.7 insects) and reduced seed damage by $80 \%$ with a WPI of between 33.3 and $10.0 \%$. Proximate analysis and germination tests indicated that the treatment materials increased the moisture and crude fibre content, decreased crude protein content but had no significant effect on the viability of stored seeds. Organoleptic tests demonstrated that treatment materials had no significant negative effect on taste, odour, texture, appearance and overall acceptability of cooked cowpea seeds after six months of storage. It can be safely concluded that the powdered form of $P$. guineense seed at the highest doses $(5.0$ and $10.0 \mathrm{~g}$ ) gave significant protection of cowpea seeds against the cowpea bruchid, which compared favourably with actellic dust when applied topically.
\end{abstract}

* Corresponding author: frankojiako@gmail.com 
KEY WORDS: Cowpea, Organoleptic tests. Piper guineense, Proximate analysis, Seed damage, Weevil perforation index.

\section{INTRODUCTION}

One of the greatest challenges facing the world today is to produce sufficient amounts of food for the growing population, which is expected to exceed 8.5 billion by the year 2030 and 9.7 billion by 2050 (UN DESA 2015). Of this, sub-Saharan Africa is projected to reach a population of about 1.96 billion or 21 percent of the global population (ALEXANDRATOS \& BRUINSMA 2012) with an expected food demand growth of $60-70 \%$ by 2050 (GODFRAY et al. 2010, Mollins 2016). The scenario is particularly critical in Nigeria, where agricultural production is barely adequate to meet even current needs of her over 180 million population, mainly due to heavy post-harvest losses and quality deterioration caused by storage pests, especially insects.

YOUDEOWI (1980) and FAKAYODE et al. (2014) estimated the loss due to insects to be $10-100 \%$ for cowpea and noted that the greatest loss to this pulse in storage is caused by the cowpea seed beetle Callosobruchus maculatus (FABRICIUS, 1775). This loss has been projected at between 2.44 and 3.67 million tonnes of cowpea (IDACHABA \& OLAYIDE 1976). It is not enough, therefore, to increase pulse production to combat protein deficiency prevalent in developing countries: there is a real need to reduce quantitative and qualitative losses during storage (AGARWAL et al. 1988).

Cowpea Vigna unguiculata (L.) WALP. belongs to the family Leguminosae, subfamily Papilionoideae and genus Vigna (VERDCOURT 1970). It is acknowledged as "vegetable meat" (OYEWALE \& BAMAIYI 2013), because of its high protein content and is the major protein source for more than 200 million people in sub-Saharan Africa (ENV/JM/MONO 2015). Nigeria is the largest producer and consumer of cowpeas, accounting for $61 \%$ of production in Africa and 58\% worldwide (IITA 2012).

The cowpea bruchid, Callosobruchus maculatus, a member of the subfamily Bruchinae (seed beetles) in the family Chrysomelidae (KERGOAT et al. 2007), is a field-to-store pest and the most important pest of stored cowpea (CASWELL 1980). Infestation begins by adults laying eggs on mature pods in the field, each female laying up to 100 eggs (BECK \& BLUMER 2014). Adult emergence usually occurs after harvest in the store.

Management of cowpea seed storage pests relies heavily on the use of chemical insecticides (TIROESELE et al. 2015). These include chemicals such as lindane, dichlorvos, fumigants like phosphine tablets, ethylene dibromide, hydrogen cyanide and methyl bromide, as well as synthetic pyrethroids like permethrin and deltamethrin. Pirimiphosmethyl (actellic 2\% dust) (O-(2-(diethylamino)-6-methyl-4-pyrimidinyl)-O, O-dimethyl 
phosphorothioate), used for comparative purposes in this study, is the synthetic insecticide of choice in Nigeria. It is used in large-scale commercial agricultural applications as well as in consumer products for domestic purposes (ISMAN 2006, ACES 2017), especially where there is high vector resistance to pyrethroids and organochlorines (FUSEINI et al. 2011).

Despite the efficacy of these synthetic insecticides, several adverse effects have reportedly emerged from their misuse. These include: insect resistance, pest resurgence, health hazards, biomagnification of toxic residues in the trophic chain, increasing costs of application, widespread environmental hazards, poisonings of humans and domestic animals, destruction of natural enemies and contamination of underground waters and rivers (AYOOLA \& AJANI 2008, GRZYWACZ \& LEAVETT 2012). These debilitating effects have directed the need for effective but relatively safe, eco-friendlier, readily available and biodegradable botanical pesticides (TALUKDER \& HOWSE 2000, DAYAN et al. 2009).

Piper guineense SCHUMACH.., a spice plant from the class Magnoliopsida, order Piperales and family Piperaceae, is an important plant that has culinary, medicinal, cosmetic and insecticidal uses (JULIANI et al. 2013, BESONG et al. 2016). The plant is found in tropical regions of central and west Africa, where it is semi-cultivated in countries like Nigeria, especially in the southern parts (PURSEGLOVE et al. 1981). It is known in Nigeria as 'Uziza' (Igbo), 'Iyere' (Yoruba) and 'Masooro' (Hausa). Other common names are Ashanti pepper, Guinea pepper, Benin pepper and false cubeb.

Piper guineense is an important source of various nutrients and phytochemicals such as proteins, carbohydrates, vitamins, minerals, fat, alkaloids, steroids, lignins, glycosides, saponins, flavonoids, tannins and phenolic compounds. It is also known to have antibacterial, antioxidant, anti-inflammatory, hepatoprotective, fertility, aphrodisiac, anticonvulsant and larvicidal properties (ЕсHO et al. 2012, OKOYE \& EBELEDIKE 2013, NWANKWO et al. 2014, BESONG et al. 2016, UKPAI et al. 2017).

The seeds contain piperine and chavicine, which are reported to have active insecticidal ingredients (OKONKWO \& OKOYE 1996). Recent studies have shown that Piper guineense can be used as an alternative in the control of insect pests in vegetable production. OKUNLOLA \& AKINRINNOLA (2014) reported that a $P$. guineense extract was effective in the control of insect pests of Telferia occidentalis HoOK. F., Amaranthus hybridus L. (African spinach) and Abelmoschus esculentus (L.) MOENCH (Okra), while IBEKWE et al. (2014) showed that the bio-insecticide was effective in the control of insect pests of Solanum spp. L. (garden egg). UKPAI et al. (2017) recently reported the insecticidal potential of Piper guineense seed powder against Sitophilus zeamais (MOTSCHULSKY, 1855) in stored corn grain.

Since chemical control is inappropriate for the small-scale farmer (VAN HUIS 1991) and local farmers are mostly receptive to storage protection methods that lie within their technical and financial means (TAYLOR 1975), this study aims at confirming and or 
identifying insecticidal activity in Piper guineense and its effective rates when compared with a known insecticide. It goes further in that it establishes whether the plant product has effects on the viability, nutritional and organoleptic qualities of stored cowpea seeds. This should increase the diversity of plant biocides that can serve as models for the synthesis of new insecticidal compounds.

\section{MATERIALS AND METHODS}

\section{Laboratory Culture of Callosobruchus maculatus}

Adult $C$. maculatus were collected from infested cowpea seeds from 'Oja Oba' market in Ilorin, Nigeria. Insects were introduced into two breeding containers with susceptible cowpea seeds at ambient temperature $\left(28 \pm 3^{\circ} \mathrm{C}\right)$ and a relative humidity of $75 \pm 5 \%$. These were used to establish a laboratory culture.

\section{Collection and Preparation of Cowpea Seeds}

Some quantities of untreated cowpea seeds Vigna unguiculata cv. TVU 3629 were collected from the International Institute for Tropical Agriculture (IITA), Ibadan, Nigeria. The seeds were air-dried in the laboratory to prevent mould, after which they were sorted, sealed in a cellophane bag and put in a deep freezer (for two weeks) for thorough disinfestation. Prior to use, the seeds were air-dried for $4 \mathrm{~h}$. One hundred grams of seeds were weighed out into $250 \mathrm{ml}$ translucent plastic tubes, which were covered with clean baft cloth to allow the inflow of air and to mimic storage conditions in jute bags. There were altogether 21 translucent plastic tubes (with $100 \mathrm{~g}$ cowpea seeds) for the envisaged treatment replicates.

\section{Procurement and Preparation of Treatment Materials}

Ripe seeds of Piper guineense were collected from a bush near the University of Ilorin, Nigeria. The collected seeds were air-dried, pulverized into fine powder, properly sieved with a 10-micron sieve and sealed in cellophane bags. Actellic 2\% dust (Pirimiphosmethyl) was purchased from Syngenta, Agege Road, Lagos, Nigeria.

\section{Treatment and Storage of Cowpea Seeds}

Weights of Piper guineense seed powder $(2.5 \mathrm{~g}, 5.0 \mathrm{~g}, 10.0 \mathrm{~g})$ and actellic $2 \%$ dust (1.0 $\mathrm{g}, 2.0 \mathrm{~g}, 3.0 \mathrm{~g})$ were measured out, respectively, including a control $(0.00 \mathrm{~g})$. The seven treatments were replicated thrice, making a total of 21 replicates, and put into the $250 \mathrm{ml}$ plastic tubes with $100 \mathrm{~g}$ of clean cowpea seeds in each tube. The cowpea seeds were 
thoroughly mixed with the test materials and laid out in a completely randomized design in the laboratory. The controls $(0.00 \mathrm{~g})$ had neither plant product nor actellic dust added.

\section{Bioassay}

Twenty-four hours after test material application, 50 seeds from each of the treated and untreated (control) cowpea seeds were placed in new $100 \mathrm{ml}$ plastic tubes. Five pairs of male and female Callosobruchus maculatus were introduced into each of the plastic tubes, which were covered with baft cloth and tied firmly with a rubber band. For sex differentiation, the elytral pattern of female $C$. maculatus is usually maculate whereas that of the male is plain. The females are dark coloured and possess four elytral spots, while males are brown and less distinctly spotted. The females of most strains are larger than the males and have large, dark-coloured plates covering the end of their abdomen (HALSTEAD 1963, BECK \& BLUMER 2014).

Effect on Mortality: The effect of the plant materials on the mortality of the adults was assessed $24 \mathrm{~h}, 48 \mathrm{~h}$ and seven days after treatment. At 24 and $48 \mathrm{~h}$, the dead insects were discarded. The percentage mortality was calculated using the formula:

$$
\text { Percentage Mortality (\%) }=\frac{\text { No. of dead insects }}{\text { Total No. of insects }} \times 100
$$

Effect on Oviposition: The number of eggs laid on the cowpeas was recorded on the $7^{\text {th }}$ day on a sub-sample of 10 randomly selected seeds. The distribution of the eggs was also recorded.

Effect on Adult Emergence: The total number of emerged $F_{1}$ adults (dead and alive) were counted on the first day that emergence was noticed ( $23 \pm 1$ days after introduction of insects). On this day, all the insects, dead and alive, were removed from the jars in order to distinguish them from those that would emerge later.

Effect on Seed Damage: Damage was assessed by the total number and distribution of holes per cowpea seed. The number of holes per sample of 10 randomly selected seeds and the number of these seeds with holes was recorded for damage assessment. These were checked and recorded on the same date and time that the first emerging adults were noticed.

The percentage of perforated grains and the Weevil Perforation Index (WPI) (FATOPE et al. 1995) was calculated thus:

$$
\text { Percentage Grains }(\%)=\frac{\text { No. of perforated grains }}{\text { Total number of grains }} \times 100
$$


A weevil perforation index value exceeding 50 is regarded as enhancement of infestation by the weevil or the negative protective ability of the plant material or insecticide tested.

\section{Residual Tests}

To assess the residual effect of Piper guineense seed powder and actellic dust on stored seeds, the above procedures were repeated after the first, second, third, fourth, fifth and sixth months of storage of the original $100 \mathrm{~g}$ seeds. Fifty seeds were taken each month from the stock, placed in clean $100 \mathrm{ml}$ plastic tubes and five pairs of insects introduced, as at the start of the experiment.

\section{Sample analyses}

Proximate Analysis: The first analysis was done with 3 replicates of untreated cowpeas after disinfestation and air drying of the procured seeds at the outset of the experiment. The aim was to determine base values for the seeds to be compared with the values obtained after storage with the treatment materials. The standard methods of the Association of Official Analytical Chemists (AOAC 2005) were used to determine moisture, crude fat, crude protein, total ash and crude fibre content. All the analyses were carried out in triplicate.

The second sample analysis was done six months after the cowpea seeds had been stored with the different rates of plant materials and actellic dust. The test plant material and actellic dust were very carefully sieved off the seeds before the analyses. Similar procedures as in the previous case were used.

Viability Tests: For the first viability test, 30 cowpea seeds were selected from the reserve of untreated seeds. Ten seeds each were placed in three Petri dishes, whose bases were lined with Whatman No.44 filter paper moistened with water. The experiment was left for seven days to ensure all the viable seeds germinated. Numbers of emerged seedlings per Petri dish were recorded seven days after set-up. The next germination test was carried out six months after the onset of the experiment. Ten seeds were randomly taken from the stored samples and placed in Petri dishes laid out as described above. This gave a total of 21 Petri dishes. As before, numbers of emerged seedlings per Petri dish were recorded seven days after set-up. The percentage germination was calculated using the following formula:

$$
\text { Percentage germination }(\%)=\frac{\text { No. of germinated seeds }}{\text { No. of seeds planted }} \times 100
$$


Organoleptic Evaluation: Only the highest rates $(10.0 \mathrm{~g} / 100 \mathrm{~g}$ seed for Piper guineense and $3.0 \mathrm{~g} / 100 \mathrm{~g}$ seed for pirimiphos-methyl) were used. This gave a total of three samples (including a control). The highest rate was chosen to bring out the 'best' or 'worst' organoleptic property, as the case may be.

One hundred grams $(100 \mathrm{~g})$ each of the samples were washed and cooked with clean water in clean pots over a gas cooker with four cooking points and boiled for $65 \mathrm{~min}$. No extraneous flavours were added to the cooking and the samples were presented to panellists at the same temperature (LARMOND 1977). To eliminate subconscious bias in the panellists, cryptic labelling was employed. Samples were labelled A to C. The cooked seeds were served to a panel of ten judges in a tasting room devoid of environmental interferences of extraneous odour and noise. Questionnaires were drawn up to determine the sought-after parameters, that is, taste, odour, texture, appearance and overall acceptability. A five-point hedonic scale method (AMERINE et al. 1965) with scores ranging from 0 to 4 , where 0 is bad and 4 excellent, was used to rate the cooked seeds.

\section{RESULTS}

\section{Effect of Actellic Dust}

Very high mortality of adult Callosobruchus maculatus $(73.3-100.0 \%)$ was recorded within $24 \mathrm{~h}$, in the first four months, in cowpea seeds treated with actellic dust (Table 1). The untreated seeds recorded between $0.0-6.7 \%$ mortality within the same period. Seeds treated with actellic dust also had a very low number and distribution of eggs throughout the six months of the experiment (Table 2). The highest number of eggs laid per seed, for the first four months of the experiment, was 0.7 eggs, while a maximum of about $33.0 \%$ seeds were oviposited on as against the 5.6 eggs, and $100 \%$ of the seeds in the untreated control, respectively. The synthetic inhibited the emergence of adult $C$. maculatus in treated samples during the six months of storage (Table 3) with the highest emergence of 14.7 insects as against 272.7 insects in the control. The least number of damaged cowpea seeds stored over the six-month period of storage (Table 4) was also recorded in seeds treated with the synthetic. The mean number of holes per seed and the number of seeds with holes ranged from 0.0 to 0.3 and $0.0-3.3$, respectively, whereas that of the untreated control, ranged from 1.4 to 3.8 holes/seed and from 8.7 to 10.0 seeds with holes, respectively. A Weevil Protection Index of between $0.00-33.3 \%$ was recorded, indicating that actellic had better protection ability. There were no significant differences between the rates of application. However, it appears that the medium and highest rates, 2.0 and $3.0 \mathrm{~g} / 100$ 
Table 1. Efficacy of Piper guineense seed powders and Actellic $2 \%$ dust on adult mortality of Callosobruchus maculatus. (c) - control.

\begin{tabular}{|c|c|c|c|c|}
\hline Materials & Rate (g/ 100g) & $24 \mathrm{hr}$ & $48 \mathrm{hr}$ & 7 days \\
\hline \multicolumn{5}{|c|}{ Commencement } \\
\hline \multirow[t]{3}{*}{ Actellic dust } & 1.0 & $96.7 \mathrm{a}$ & $100.0 \mathrm{a}$ & $100.0 \mathrm{a}$ \\
\hline & 2.0 & $100.0 \mathrm{a}$ & $100.0 \mathrm{a}$ & $100.0 \mathrm{a}$ \\
\hline & 3.0 & $96.7 \mathrm{a}$ & $100.0 \mathrm{a}$ & $100.0 \mathrm{a}$ \\
\hline \multirow[t]{4}{*}{ P. guineense } & 2.5 & $13.3 \mathrm{de}$ & $66.7 \mathrm{c}$ & $100.0 \mathrm{a}$ \\
\hline & 5.0 & $20.0 \mathrm{~cd}$ & $63.3 \mathrm{c}$ & $100.0 \mathrm{a}$ \\
\hline & 10.0 & $36.7 \mathrm{~b}$ & $76.7 \mathrm{~b}$ & $100.0 \mathrm{a}$ \\
\hline & $0.0(\mathrm{c})$ & $0.0 \mathrm{f}$ & $3.3 \mathrm{ef}$ & $36.7 \mathrm{c}$ \\
\hline \multirow[t]{2}{*}{ S. E. M. } & & 2.8 & 3.3 & 4.4 \\
\hline & & Month 2 & & \\
\hline \multirow[t]{3}{*}{ Actellic dust } & 1.0 & $100.0 \mathrm{a}$ & $100.0 \mathrm{a}$ & $100.0 \mathrm{a}$ \\
\hline & 2.0 & $100.0 \mathrm{a}$ & $100.0 \mathrm{a}$ & $100.0 \mathrm{a}$ \\
\hline & 3.0 & $100.0 \mathrm{a}$ & $100.0 \mathrm{a}$ & $100.0 \mathrm{a}$ \\
\hline \multirow[t]{4}{*}{ P. guineense } & 2.5 & $43.3 \mathrm{~b}$ & $56.7 \mathrm{de}$ & $96.7 \mathrm{ab}$ \\
\hline & 5.0 & $40.0 \mathrm{bc}$ & $76.7 \mathrm{bc}$ & $96.7 \mathrm{ab}$ \\
\hline & 10.0 & $36.7 \mathrm{bc}$ & $90.0 \mathrm{ab}$ & $100.0 \mathrm{a}$ \\
\hline & $0.0(\mathrm{c})$ & $6.7 \mathrm{gh}$ & 30.0 ef & $63.3 \mathrm{~cd}$ \\
\hline \multirow[t]{2}{*}{ S. E. M. } & & 4.5 & 6.2 & 7.6 \\
\hline & & Month 4 & & \\
\hline \multirow[t]{3}{*}{ Actellic dust } & 1.0 & $73.3 \mathrm{~b}$ & $90.0 \mathrm{a}$ & $100.0 \mathrm{a}$ \\
\hline & 2.0 & $100.0 \mathrm{a}$ & $100.0 \mathrm{a}$ & $100.0 \mathrm{a}$ \\
\hline & 3.0 & $100.0 \mathrm{a}$ & $100.0 \mathrm{a}$ & $100.0 \mathrm{a}$ \\
\hline \multirow[t]{4}{*}{ P. guineense } & 2.5 & $10.0 \mathrm{e}$ & $43.3 \mathrm{c}$ & $96.7 \mathrm{a}$ \\
\hline & 5.0 & $10.0 \mathrm{de}$ & $40.0 \mathrm{c}$ & $96.7 \mathrm{a}$ \\
\hline & 10.0 & $16.7 \mathrm{~cd}$ & $60.0 \mathrm{~b}$ & $100.0 \mathrm{a}$ \\
\hline & $0.0(\mathrm{c})$ & $0.0 \mathrm{f}$ & & \\
\hline \multirow[t]{2}{*}{ S. E. M. } & & 2.1 & 3.4 & 4.0 \\
\hline & & Month 6 & & \\
\hline \multirow[t]{3}{*}{ Actellic dust } & 1.0 & $30.0 \mathrm{~b}$ & $56.7 \mathrm{~b}$ & $96.7 \mathrm{ab}$ \\
\hline & 2.0 & $33.3 \mathrm{~b}$ & $63.3 \mathrm{~b}$ & $100.0 \mathrm{a}$ \\
\hline & 3.0 & $43.3 \mathrm{a}$ & $76.7 \mathrm{a}$ & $100.0 \mathrm{a}$ \\
\hline \multirow[t]{4}{*}{ P. guineense } & 2.5 & $0.0 \mathrm{f}$ & 30.0 ef & $100.0 \mathrm{a}$ \\
\hline & 5.0 & $0.0 \mathrm{f}$ & $20.0 \mathrm{f}$ & $100.0 \mathrm{a}$ \\
\hline & 10.0 & 10.0 & $20.0 \mathrm{f}$ & $100.0 \mathrm{a}$ \\
\hline & $0.0(\mathrm{c})$ & $0.0 \mathrm{f}$ & $3.3 \mathrm{~g}$ & $86.7 \mathrm{c}$ \\
\hline S. E. M. & & 1.62 & 3.23 & 2.82 \\
\hline
\end{tabular}

Means followed by the same letter(s) in each section of the same column are not significantly different at $\mathrm{P} \leq 0.05$ using the New Duncan Multiple range test. 
Table 2. Efficacy of Piper guineense seed powders and Actellic $2 \%$ dust on oviposition of adult Callosobruchus maculatus. (c) - control.

\begin{tabular}{|c|c|c|c|}
\hline Materials & Rate (g/ 100g) & No. of eggs/seed & No. of seeds with egg \\
\hline \multicolumn{4}{|c|}{ Commencement } \\
\hline \multirow[t]{3}{*}{ Actellic dust } & 1.0 & $0.7 \mathrm{ab}$ & $3.3 \mathrm{~b}$ \\
\hline & 2.0 & $0.5 \mathrm{a}$ & $1.7 \mathrm{a}$ \\
\hline & 3.0 & $0.5 \mathrm{a}$ & $3.0 \mathrm{a}$ \\
\hline \multirow[t]{4}{*}{ P. guineense } & 2.5 & $1.1 \mathrm{ab}$ & $3.3 \mathrm{ab}$ \\
\hline & 5.0 & $0.5 \mathrm{a}$ & $2.0 \mathrm{ab}$ \\
\hline & 10.0 & $0.7 \mathrm{ab}$ & $4.0 \mathrm{~b}$ \\
\hline & $0.0(\mathrm{c})$ & $5.6 \mathrm{~cd}$ & $10.0 \mathrm{de}$ \\
\hline \multirow[t]{2}{*}{ S. E. M. } & & 0.64 & 0.66 \\
\hline & & Month 2 & \\
\hline \multirow[t]{3}{*}{ Actellic dust } & 1.0 & $0.2 \mathrm{a}$ & $1.0 \mathrm{a}$ \\
\hline & 2.0 & $0.1 \mathrm{a}$ & $0.7 \mathrm{a}$ \\
\hline & 3.0 & $0.1 \mathrm{a}$ & $0.3 \mathrm{a}$ \\
\hline \multirow[t]{4}{*}{ P. guineense } & 2.5 & $0.3 \mathrm{ab}$ & $6.7 \mathrm{~cd}$ \\
\hline & 5.0 & $0.9 \mathrm{bc}$ & $4.3 \mathrm{~b}$ \\
\hline & 10.0 & $1.0 \mathrm{bc}$ & $1.7 \mathrm{ab}$ \\
\hline & $0.0(\mathrm{c})$ & $2.9 \mathrm{c}$ & $9.7 \mathrm{~d}$ \\
\hline \multirow[t]{2}{*}{ S. E. M. } & & 0.51 & 0.69 \\
\hline & & Month 4 & \\
\hline \multirow[t]{3}{*}{ Actellic dust } & 1.0 & $0.2 \mathrm{a}$ & $2.0 \mathrm{a}$ \\
\hline & 2.0 & $0.2 \mathrm{a}$ & $1.0 \mathrm{a}$ \\
\hline & 3.0 & $0.1 \mathrm{a}$ & $1.0 \mathrm{a}$ \\
\hline \multirow[t]{4}{*}{ P. guineense } & 2.5 & $1.7 \mathrm{~b}$ & 8.0 ef \\
\hline & 5.0 & $1.5 \mathrm{ab}$ & $7.7 \mathrm{de}$ \\
\hline & 10.0 & $1.4 \mathrm{ab}$ & $7.7 \mathrm{de}$ \\
\hline & $0.0(\mathrm{c})$ & $4.8 \mathrm{~cd}$ & $10.0 \mathrm{e}$ \\
\hline \multirow[t]{2}{*}{ S. E. M. } & & 1.01 & 0,36 \\
\hline & & Month 6 & \\
\hline \multirow[t]{3}{*}{ Actellic dust } & 1.0 & $30.7 \mathrm{a}$ & $5.7 \mathrm{c}$ \\
\hline & 2.0 & $0.4 \mathrm{a}$ & $4.0 \mathrm{~b}$ \\
\hline & 3.0 & $0.2 \mathrm{a}$ & 20. a \\
\hline \multirow[t]{4}{*}{ P. guineense } & 2.5 & $1.6 \mathrm{ab}$ & $7.0 \mathrm{~d}$ \\
\hline & 5.0 & $1.1 \mathrm{a}$ & $5.3 \mathrm{a}$ \\
\hline & 10.0 & $1.0 \mathrm{a}$ & $4.7 \mathrm{bc}$ \\
\hline & 0.0 (c) & $8.2 \mathrm{~d}$ & $10.0 \mathrm{ef}$ \\
\hline S. E. M. & & 0.68 & 0.40 \\
\hline
\end{tabular}

Means followed by the same letter(s) in each section of the same column are not significantly different at $\mathrm{P} \leq 0.05$ using the New Duncan Multiple range test. 
Table 3. Efficacy of Piper guineense seed powders and Actellic $2 \%$ dust on emergence of adult Callosobruchus maculatus ( $\mathrm{F}_{1}$ Generation). (c) - control, FE - first emergence, $48 \mathrm{hr}$ - emergence at $48 \mathrm{hr}, 96 \mathrm{hr}$ - emergence at $96 \mathrm{hr}$, TCE - total cumulative emergence.

\begin{tabular}{|c|c|c|c|c|c|}
\hline Materials & Rate (g/ 100g) & FE & $48 \mathrm{hr}$ & $96 \mathrm{hr}$ & TCE \\
\hline \multicolumn{6}{|c|}{ Commencement } \\
\hline \multirow[t]{3}{*}{ Actellic dust } & 1.0 & $1.0 \mathrm{a}$ & $0.3 \mathrm{a}$ & $0.0 \mathrm{a}$ & $1.3 \mathrm{a}$ \\
\hline & 2.0 & $0.7 \mathrm{a}$ & $0.3 \mathrm{a}$ & $0.0 \mathrm{a}$ & $1.0 \mathrm{a}$ \\
\hline & 3.0 & $0.0 \mathrm{a}$ & $0.0 \mathrm{a}$ & $0.0 \mathrm{a}$ & $0.0 \mathrm{a}$ \\
\hline \multirow[t]{4}{*}{ P. guineense } & 2.5 & $21.0 \mathrm{bc}$ & $9.7 \mathrm{~b}$ & $2.3 \mathrm{ab}$ & 33.0 \\
\hline & 5.0 & $12.0 \mathrm{ab}$ & $8.0 \mathrm{~b}$ & $1.0 \mathrm{ab}$ & $21.0 \mathrm{ab}$ \\
\hline & 10.0 & $6.3 \mathrm{ab}$ & $4.7 \mathrm{ab}$ & $2.3 \mathrm{ab}$ & $13.3 \mathrm{ab}$ \\
\hline & $0.0(\mathrm{c})$ & $125.0 \mathrm{c}$ & $24.3 \mathrm{c}$ & $7.7 \mathrm{c}$ & $157.0 \mathrm{~d}$ \\
\hline \multicolumn{2}{|l|}{ S. E. M. } & 13.37 & 6.60 & 4.4 & 19.27 \\
\hline \multicolumn{6}{|c|}{ Month 2} \\
\hline \multirow[t]{3}{*}{ Actellic dust } & 1.0 & $0.0 \mathrm{a}$ & $0.0 \mathrm{a}$ & $0.0 \mathrm{a}$ & $0.0 \mathrm{a}$ \\
\hline & 2.0 & $0.0 \mathrm{a}$ & $0.0 \mathrm{a}$ & $0.0 \mathrm{a}$ & $0.0 \mathrm{a}$ \\
\hline & 3.0 & $0.0 \mathrm{a}$ & $0.0 \mathrm{a}$ & $0.0 \mathrm{a}$ & $0.0 \mathrm{a}$ \\
\hline \multirow[t]{4}{*}{ P. guineense } & 2.5 & $14.3 \mathrm{ab}$ & $1.7 \mathrm{ab}$ & $2.3 \mathrm{ab}$ & $18.3 \mathrm{ab}$ \\
\hline & 5.0 & $13.7 \mathrm{ab}$ & $4.3 \mathrm{bc}$ & $5.0 \mathrm{~cd}$ & $23.0 \mathrm{ab}$ \\
\hline & 10.0 & $9.0 \mathrm{a}$ & $3.7 \mathrm{~b}$ & $3.3 \mathrm{bc}$ & $16.0 \mathrm{ab}$ \\
\hline & $0.0(\mathrm{c})$ & $67.3 \mathrm{~b}$ & $21.3 \mathrm{c}$ & $16.0 \mathrm{~d}$ & $152.7 \mathrm{c}$ \\
\hline \multirow[t]{2}{*}{ S. E. M. } & \multirow{2}{*}{\multicolumn{4}{|c|}{ Month 4}} & 28.4 \\
\hline & & & & & \\
\hline \multirow[t]{3}{*}{ Actellic dust } & 1.0 & $0.7 \mathrm{a}$ & $0.0 \mathrm{a}$ & $0.0 \mathrm{a}$ & $0.7 \mathrm{a}$ \\
\hline & 2.0 & $0.3 \mathrm{a}$ & $0.0 \mathrm{a}$ & $0.0 \mathrm{a}$ & $0.3 \mathrm{a}$ \\
\hline & 3.0 & $0.3 \mathrm{a}$ & $0.0 \mathrm{a}$ & $0.0 \mathrm{a}$ & $0.3 \mathrm{a}$ \\
\hline \multirow[t]{4}{*}{ P. guineense } & 2.5 & $13.7 \mathrm{a}$ & $2.7 \mathrm{a}$ & $0.7 \mathrm{a}$ & $17.0 \mathrm{ab}$ \\
\hline & 5.0 & $10.7 \mathrm{a}$ & $2.7 \mathrm{a}$ & $1.7 \mathrm{ab}$ & $15.0 \mathrm{ab}$ \\
\hline & 10.0 & $18.3 \mathrm{a}$ & $2.0 \mathrm{a}$ & $2.7 \mathrm{bc}$ & $13.0 \mathrm{ab}$ \\
\hline & $0.0(\mathrm{c})$ & $99.0 \mathrm{c}$ & $37.3 \mathrm{~b}$ & $16.3 \mathrm{~d}$ & $152.7 \mathrm{c}$ \\
\hline \multicolumn{2}{|l|}{ S. E. M. } & 19.57 & 6.83 & 4.22 & 28.4 \\
\hline \multicolumn{6}{|c|}{ Month 6} \\
\hline \multirow[t]{3}{*}{ Actellic dust } & 1.0 & $9.7 \mathrm{a}$ & $3.0 \mathrm{a}$ & $2.0 \mathrm{a}$ & $14.7 \mathrm{a}$ \\
\hline & 2.0 & $5.7 \mathrm{a}$ & $0.7 \mathrm{a}$ & $1.0 \mathrm{a}$ & $7.3 \mathrm{a}$ \\
\hline & 3.0 & $4.0 \mathrm{a}$ & $1.3 \mathrm{a}$ & $0.0 \mathrm{a}$ & $5.3 \mathrm{a}$ \\
\hline \multirow[t]{4}{*}{ P. guineense } & 2.5 & $19.0 \mathrm{a}$ & $13.3 \mathrm{a}$ & $6.0 \mathrm{ab}$ & $38.3 \mathrm{a}$ \\
\hline & 5.0 & $15.3 \mathrm{a}$ & $5.7 \mathrm{a}$ & $3.3 \mathrm{a}$ & $24.3 \mathrm{a}$ \\
\hline & 10.0 & $7.3 \mathrm{a}$ & $3.3 \mathrm{a}$ & $1.3 \mathrm{a}$ & $12.0 \mathrm{a}$ \\
\hline & $0.0(\mathrm{c})$ & $189.7 \mathrm{c}$ & $56.3 \mathrm{~b}$ & $26.7 \mathrm{c}$ & $272.7 \mathrm{~b}$ \\
\hline S. E. M. & & 13.24 & 5.87 & 3.11 & 15.9 \\
\hline
\end{tabular}

Means followed by the same letter(s) in each section of the same column are not significantly different at $\mathrm{P} \leq 0.05$ using the New Duncan Multiple range test. 
Table 4. Efficacy of Piper guineense seed powders and Actellic $2 \%$ dust on the damage assessment of stored cowpea seeds. (c) - control.

\begin{tabular}{|c|c|c|c|c|}
\hline Materials & Rate (g/ 100g) & No. of holes/seed & $\begin{array}{c}\text { No. of seeds with } \\
\text { holes }\end{array}$ & $\begin{array}{l}\text { Weevil perforation } \\
\text { index (WPI) }\end{array}$ \\
\hline \multicolumn{5}{|c|}{ Commencement } \\
\hline \multirow[t]{3}{*}{ Actellic dust } & 1.0 & $0.0 \mathrm{a}$ & $0.3 \mathrm{a}$ & $3.3 \mathrm{a}$ \\
\hline & 2.0 & $0.0 \mathrm{a}$ & $0.0 \mathrm{a}$ & $0.0 \mathrm{a}$ \\
\hline & 3.0 & $0.0 \mathrm{a}$ & $0.0 \mathrm{a}$ & $0.0 \mathrm{a}$ \\
\hline \multirow[t]{4}{*}{ P. guineense } & 2.5 & $0.3 \mathrm{a}$ & $2.0 \mathrm{ab}$ & $20.0 \mathrm{bc}$ \\
\hline & 5.0 & $0.1 \mathrm{a}$ & $1.0 \mathrm{a}$ & $10.0 \mathrm{ab}$ \\
\hline & 10.0 & $0.1 \mathrm{a}$ & $1.0 \mathrm{a}$ & $10.0 \mathrm{ab}$ \\
\hline & $0.0(\mathrm{c})$ & $2.6 \mathrm{~d}$ & $10.0 \mathrm{~d}$ & - \\
\hline S. E. M. & & 0.37 & 0.72 & 8.29 \\
\hline \multicolumn{5}{|c|}{ Month 2} \\
\hline \multirow[t]{3}{*}{ Actellic dust } & 1.0 & $0.0 \mathrm{a}$ & $0.0 \mathrm{a}$ & $0.0 \mathrm{a}$ \\
\hline & 2.0 & $0.0 \mathrm{a}$ & $0.0 \mathrm{a}$ & $0.0 \mathrm{a}$ \\
\hline & 3.0 & $0.0 \mathrm{a}$ & $0.0 \mathrm{a}$ & $0.0 \mathrm{a}$ \\
\hline \multirow[t]{4}{*}{ P. guineense } & 2.5 & $0.5 \mathrm{ab}$ & $3.3 \mathrm{bc}$ & $40.5 \mathrm{~cd}$ \\
\hline & 5.0 & $0.5 \mathrm{ab}$ & $3.3 \mathrm{bc}$ & $37.7 \mathrm{bc}$ \\
\hline & 10.0 & $0.3 \mathrm{a}$ & $2.0 \mathrm{ab}$ & $23.7 \mathrm{ab}$ \\
\hline & $0.0(\mathrm{c})$ & $1.4 \mathrm{~d}$ & $8.7 \mathrm{~d}$ & - \\
\hline S. E. M. & & 0.28 & 0.92 & 11.85 \\
\hline \multicolumn{5}{|c|}{ Month 4} \\
\hline \multirow[t]{3}{*}{ Actellic dust } & 1.0 & $0.0 \mathrm{a}$ & $0.0 \mathrm{a}$ & $0.0 \mathrm{a}$ \\
\hline & 2.0 & $0.0 \mathrm{a}$ & $0.3 \mathrm{a}$ & $3.3 \mathrm{a}$ \\
\hline & 3.0 & $0.0 \mathrm{a}$ & $0.0 \mathrm{a}$ & $0.0 \mathrm{a}$ \\
\hline \multirow[t]{4}{*}{ P. guineense } & 2.5 & $0.5 \mathrm{ab}$ & $2.0 \mathrm{c}$ & 21.2. bc \\
\hline & 5.0 & $0.4 \mathrm{ab}$ & $2.7 \mathrm{c}$ & $27.8 \mathrm{c}$ \\
\hline & 10.0 & $0.3 \mathrm{ab}$ & $9.7 \mathrm{~d}$ & $24.1 \mathrm{c}$ \\
\hline & $0.0(\mathrm{c})$ & $2.3 \mathrm{~d}$ & $9.7 \mathrm{~d}$ & - \\
\hline S. E. M. & & 0.47 & 0.53 & 6.10 \\
\hline \multicolumn{5}{|c|}{ Month 6} \\
\hline \multirow[t]{3}{*}{ Actellic dust } & 1.0 & $0.3 \mathrm{a}$ & $3.3 \mathrm{~b}$ & $33.3 \mathrm{~b}$ \\
\hline & 2.0 & $0.2 \mathrm{a}$ & $3.0 \mathrm{~b}$ & $30.0 \mathrm{~b}$ \\
\hline & 3.0 & $0.1 \mathrm{a}$ & $1.7 \mathrm{a}$ & $16.7 \mathrm{a}$ \\
\hline \multirow[t]{4}{*}{ P. guineense } & 2.5 & $0.4 \mathrm{a}$ & $4.0 \mathrm{bc}$ & $40.5 \mathrm{bc}$ \\
\hline & 5.0 & $0.4 \mathrm{a}$ & $3.7 \mathrm{bc}$ & $40.0 \mathrm{bc}$ \\
\hline & 10.0 & $0.3 \mathrm{a}$ & $3.3 \mathrm{~b}$ & $33.3 \mathrm{~b}$ \\
\hline & $0.0(\mathrm{c})$ & $3.8 \mathrm{~b}$ & $10.0 \mathrm{e}$ & - \\
\hline S. E. M. & & 0.38 & 0.33 & 3.76 \\
\hline
\end{tabular}

Means followed by the same letter(s) in each section of the same column are not significantly different at $\mathrm{P} \leq 0.05$ using the New Duncan Multiple range test. 
$\mathrm{g}$ seed, respectively, were better than the lowest rate $(1.0 \mathrm{~g} / 100 \mathrm{~g}$ seed $)$. The medium rate, therefore, seems to be the most reasonable rate to be recommended. The seeds treated with actellic dust were clean, hard and mostly undamaged.

\section{Effect of Piper guineense}

The mortality of insects in seeds treated with $P$. guineense reached $90.0 \%$ in $48 \mathrm{~h}$ in the second month of storage (Table 1). When compared with the control, the bioinsecticide performed well in reducing the number of eggs laid throughout the six months of the experiment (Table 2). The effect of $P$. guineense in suppressing oviposition was statistically the same as in seeds treated with actellic dust. However, the eggs laid were more evenly distributed in the seeds treated with $P$. guineense than those treated with actellic dust.

Total cumulative emergence from seeds treated with $P$. guineense was consistently very low. The highest application rate $(10.0 \mathrm{~g})$ recorded a very low number of emerged insects, with the highest being 16.0 insects (as against 272.7 insects in the control), throughout the six months of the experiment (Table 3).

There were relatively few damaged cowpea seeds stored with $P$. guineense. The highest numbers of holes per seed and seeds with holes sampled were 0.60 holes and 6.0 seeds as against the 3.80 holes and 10.00 seeds in the untreated control, respectively. The WPI for the highest rate of $P$. guineense treated seeds $(10.0-33.3 \%)$ compared favourably with the protection ability of actellic dust (with a WPI of between $0.0-33.3 \%$ for the lowest rate of application). The efficacy of $P$. guineense in the experiment is discernibly dose-related, with the highest rate $(10.0 \mathrm{~g} / 100 \mathrm{~g}$ seed) performing better than the lower rates.

\section{Effect on Proximate Analysis}

Piper guineense seed powder and actellic dust increased the moisture and crude fibre content, decreased crude protein but had no discernible effect on crude fat and total ash of cowpea seeds (Figure 1). The effects were dose-related.

\section{Effect on Seed Viability}

Actellic dust and seed powder of Piper guineense used in storing the cowpea seeds had no significant effect on viability (Figure 2).

\section{Effect on Organoleptic Analysis of Cooked Cowpea Seeds}

The treatment materials had no significant effect on the taste, odour, texture, appearance and overall acceptability of cooked cowpea seeds (Figure 3). 


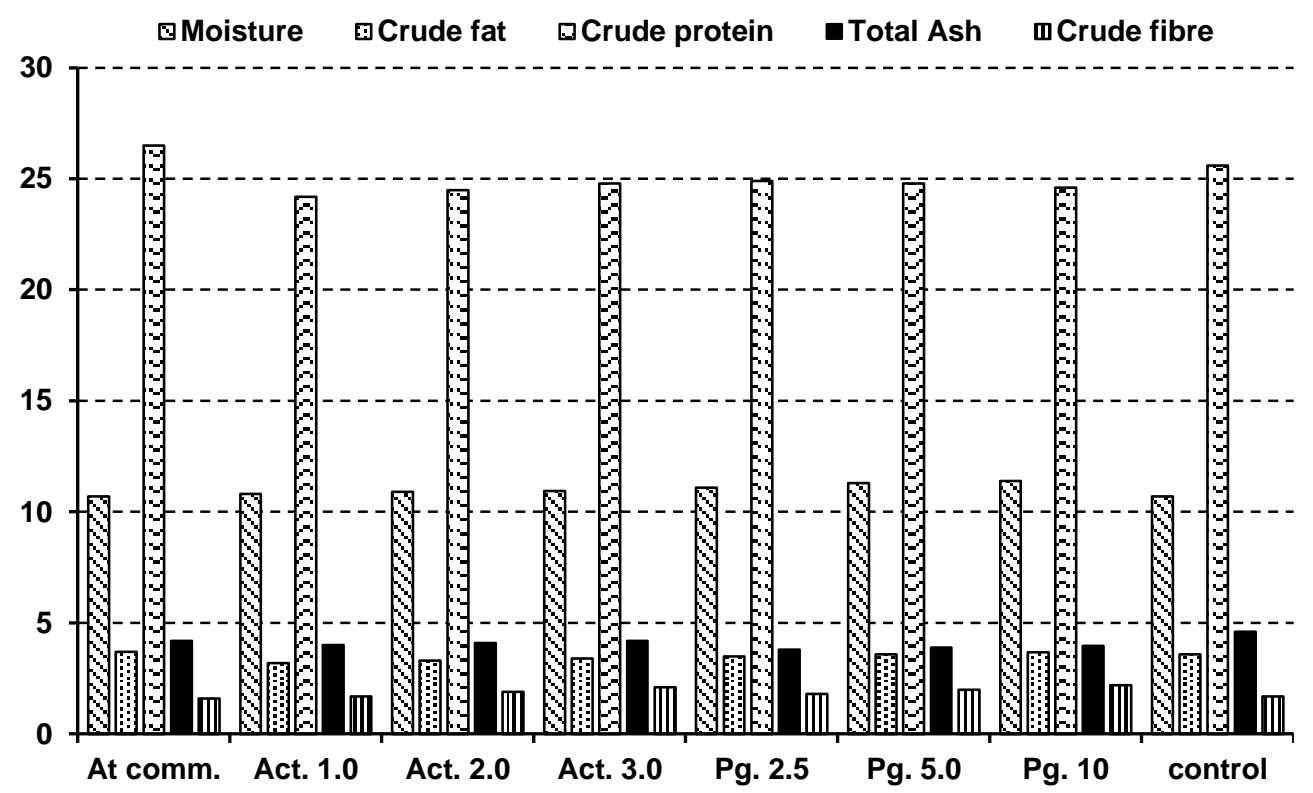

Fig. 1. Proximate analysis of cowpea seeds after treatment with Piper guineense seed powder (Pg.) and Actellic 2\% dust (Act.) at different rates.

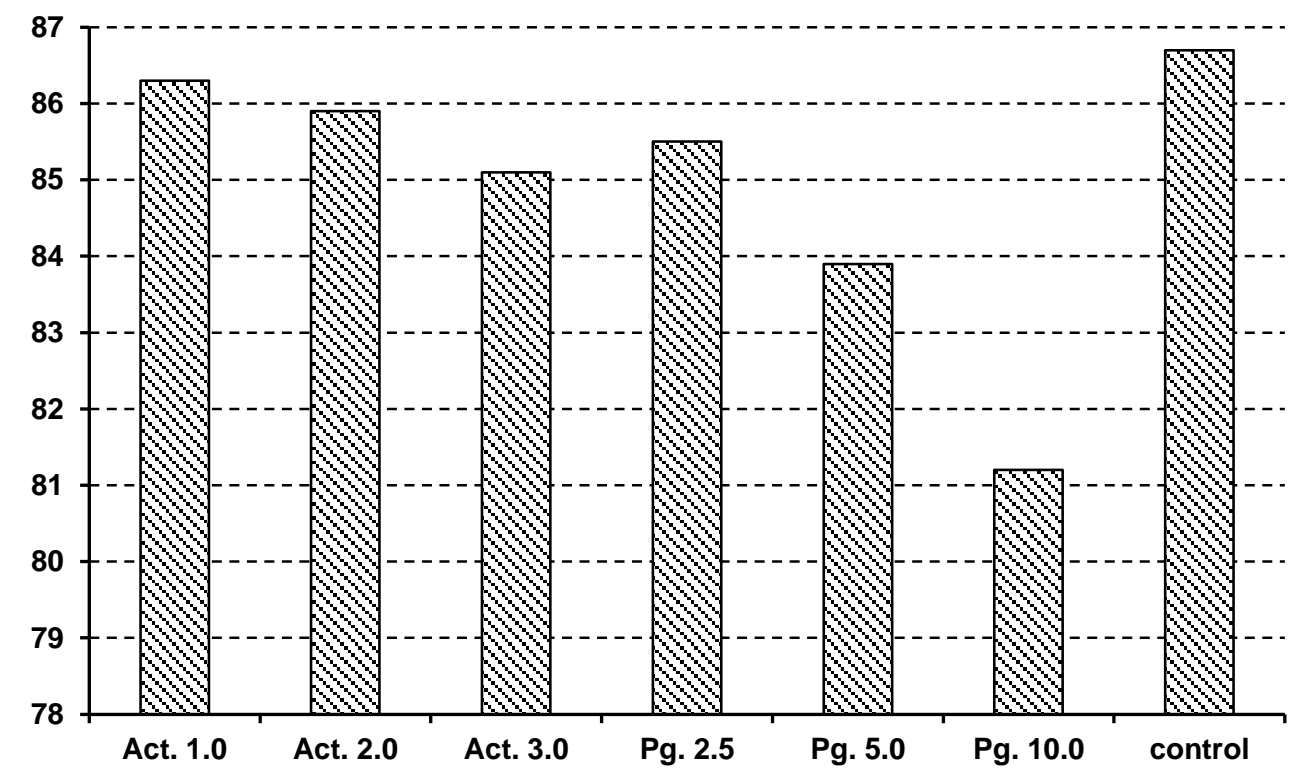

Fig. 2. Percentage germination after treatment with Piper guineense seed powder and Actellic $2 \%$ dust and storing for six months. 
$₫$ Taste $₫$ Odor $₫$ Texture $\square$ Appearance $\square$ Overall Acceptability

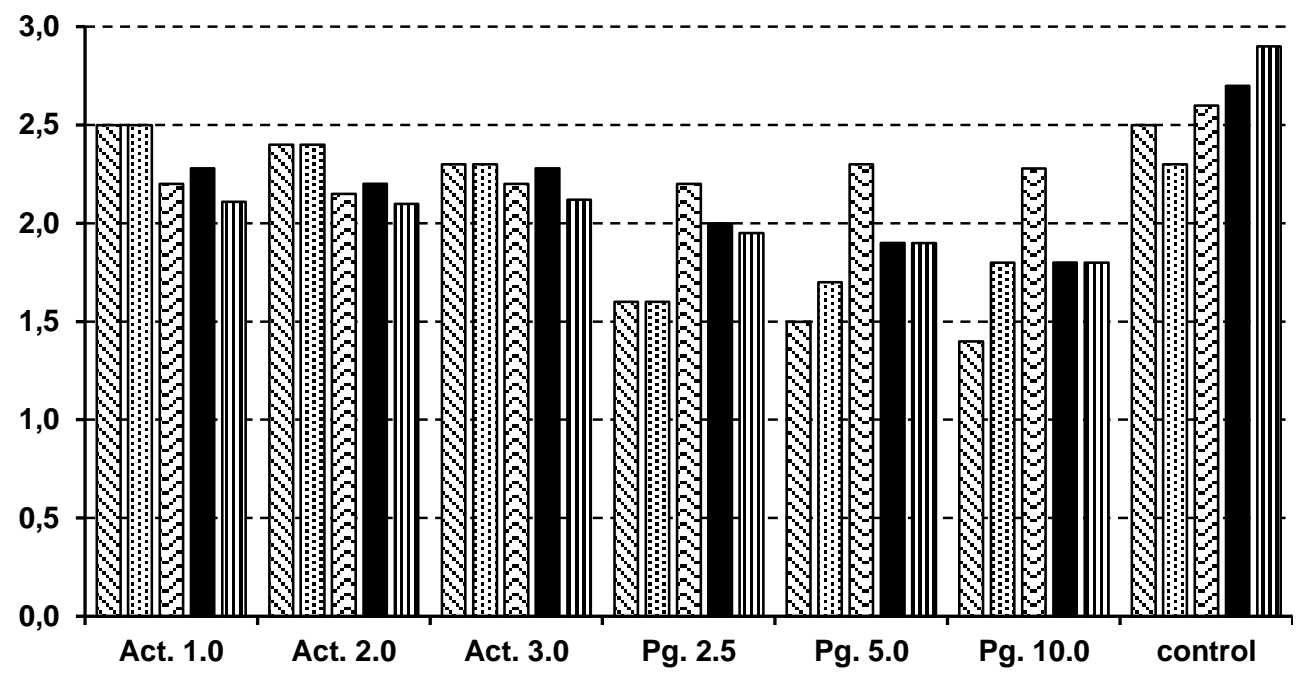

Fig. 3. Organoleptic ratings of cooked cowpea after treatment with Piper guineense seed powder (Pg.) and Actellic 2\% dust (Act.) and storing for six months.

\section{DISCUSSION}

The result obtained regarding the efficacy of actellic dust is in agreement with earlier works by OGunwolu \& Odunlami (1996), DAnKwa (1998) and Mulungu et al. (2007). In their assessment of the residual activity of pirimiphos-methyl on Callosobruchus maculatus treatment, DASBAK et al. (2009) also affirmed that the insecticide drastically reduced the developmental potential and extent of pigeonpea seed damage by the bruchid, six months post treatment. AKINKUROLERE (2012) has, however, reported that cowpea seeds treated with $4.0 \%$ pirimiphos-methyl elicited only $60.0 \%$ mortality in 4 days after treatment (DAT) when compared with Monodora myristica (GAERTN.) DUNAL (80.60\%) and Momordica charantia (L.) (69.80\%), respectively. This may well be due to the source of the pirimiphos-methyl used, as the issue of unbridled adulteration/counterfeiting of pesticides in Nigeria has been variously reported (ASOGWA \& DONGO 2009, IDRIS et al. 2013).

Pirimiphos-methyl has been found to have contact and fumigant activity (ČERŇÁKOVÁ et al. 1992, WHO 2004), is fast acting, effective at low concentrations and could, at 375 $\mathrm{ml} / 100$ litres of water, be used to control aphids (Myzus persicae SuLz.) and whiteflies (Bemsisa tabasi (GENN.)) in Okra (SHOURA CHEMICALS 2012). 
Piper guineense performed well when compared with the control in causing insect mortality and in reducing the number of eggs laid, but egg dispersal on seeds was greater. This could be the result of high insect mortality in actellic dust treated seeds within the first $24 \mathrm{~h}$, as against those in the $P$. guineense treated seeds, which gave the insects room to move about for a more even distribution of the eggs. Since the percentage mortality of insects in $P$. guineense treated seeds was far less than that of actellic dust, it does seem that $P$. guineense has an oviposition deterrent effect.

Fewer emerged insects in the higher rates of $P$. guineense during 6 months of storage indicated that the effect of the plant materials was the same despite the length of time in storage. This is contrary to the effect of actellic dust on treated seeds, which showed that the toxic/suppressant effect of the synthetic gradually started to wear off after the first 4 months. The total numbers of emerged insects in the $P$. guineense treated seeds (for all three rates) for the fourth and sixth months (45.0 and 74.6, respectively) when compared with the number of emerged insects in the control (152.7 and 272.7 insects, respectively), clearly showed that the plant material was highly effective. When compared with the relatively large number of surviving insects during the first $48 \mathrm{~h}$ of the introduction of insects into treated samples, it becomes evident that $P$. guineense not only suppressed oviposition but also inhibited subsequent emergence of adults. AKAMI et al. (2017) has observed that in cowpea seeds treated with Lippia adoensis HOCHST ex. WALP. essential oil, most of the eggs laid could not complete their life cycle, thereby leading to a reduced adult population capable of producing subsequent generations and thus limiting seed damage.

There were also relatively few damaged cowpea seeds stored with Piper guineense. The WPI of the lowest rate of actellic dust was the same as the highest rate of $P$. guineense. Extracts of $P$. guineense have been shown to have insecticidal action (IVBIJARO 1990). Later works by LALE (1992) and ASHAMO \& ODEYEMI (2001) reported that an oil extract of $P$. guineense was extremely toxic to adult Sitophilus zeamais when compared with oils from other plant products.

The potency of Piper guineense has been attributed to piperine acting in synergism with guineensine (OKOGUN et al. 1977), which was reported to be lethal to the grasshopper Zonocerus variegatus (LINNAEUS, 1758). Piperine, the main amide active in Piper guineense (SCOTT et al. 2004), acts as a neurotoxin in insects (SCOTT et al. 2008), but is considered safe to mammals (OKUNLOLA et al. 2008). UKPAI et al. (2017) have recently reported a high content of flavonoids in $P$. guineense and suggested that the presence of alkaloids, flavonoids and phenols may be responsible for the bioactivity and consequent mortality of Sitophilus zeamais in maize stored with the botanical. The piperamides found in the genus Piper L. are unique due to their bi-functional nature and its formulations also have repellent activity (IVBIJARO \& AGBAJE 1986). 
It is, however, important to note that the susceptibility of Callosobruchus maculatus to Piper guineense could vary across location sources of the bruchid. In a study to determine the tolerance of Callosobruchus maculatus populations to Piper guineense powder within Ekiti State (in Nigeria), GBAYE et al. (2015) observed that bruchids obtained from Emure were the most tolerant (LT50: 1.19 hours and 2.45 hours, respectively) while those from Ikere were the most susceptible (LT50: 0.62 hours and 1.24 hours respectively) to this botanical. Corroborating this finding, OYENIYI et al. (2015) reported that bruchid populations from the north-eastern part of Osun State (Nigeria) showed greater tolerance towards $P$. guineense than their counterparts from the south-western part of that state. OYENIYI et al. (2015) further showed that the variety of cowpea seeds has a significant effect on the efficacy of $P$. guineense. The authors reported that bruchids emerging from cowpea variety AR48V had a greater tolerance to $P$. guineense than bruchids reared on IFBV.

The observed increase in the moisture content of treated seeds showed that the treatment materials not only retained but aided the absorption of moisture. These materials could have acted as a film over the seeds, thereby protecting the seeds from evapotranspiration. This agrees with the work of BOEKE et al. (2004), which reported that leaf powder of Momordica charantia $\mathrm{L}$. was effective against weight loss of stored cowpea.

Actellic dust had no negative effect on seed viability. This is corroborated by earlier works of OGUNwOLU \& ODUNLAMI (1996), ABDUL-RAFIU (2010) and OJIAKO et al. (2013), which reported that actellic did not affect the viability of stored cowpea or maize, respectively. Ogendo et al. (2004) and AKINKUROLERE et al. (2006) also stated that plant products generally do not affect the viability of seeds treated with them. Jatropha curcas L. seed extract has been reported to have no adverse effect on the viability of stored cowpea seeds (AHUCHAOGU \& OJIAKO 2015). However, the highest rate of Piper guineense gave $81.2 \%$ germination as against the control $(86.7 \%)$, suggesting that for seeds stored for planting purposes, the medium rate of $P$. guineense should not be exceeded.

Piper guineense and actellic dust had no significant effect on the taste, odour, texture, appearance and overall acceptability of cooked cowpea seeds. This result is consistent with earlier works with actellic dust (OPARAEKE et al. 1998) and Piper guineense (OKONKWO \& OKOYE 2002). Other plant products: Capsicum spp. (ONU \& AlIYU, 1995), Allium sativum L. (OPARAEKE \& DiKe 1996), Eucalyptus L'HÉR. powder (DIKE \& MSHELIA 1997), Hyptis sauveolens (L.) POIT. (OPARAEKE et al. 2002), Denettia tripetala BAK.F. (OKONKWO \& OKOYE 2002) and Mondora myristica (Gaertn.) Dunal (OPARAEKE \& DiKE 2005) have variously been found not to affect the organoleptic qualities of stored seeds treated with them. 


\section{CONCLUSION}

Although actellic $2 \%$ dust offered the quickest control measure in the first four months of storing cowpea seeds, Piper guineense seed powder at higher concentrations offered comparatively good protection of the stored seeds. The powder did not adversely affect seed viability, proximate composition or the organoleptic characteristics of the stored seeds.

$P$. guineense, a highly nutritional and medicinal plant that is locally available, could therefore be an acceptable, cheap, safe and environmentally friendly alternative to synthetic chemicals for protecting seeds in storage. This could also increase the diversity of plant materials that could serve as models for the synthesis of new insecticidal compounds.

\section{REFERENCES}

AbDul-RAFiUa M. 2010. Effect of variety and seed treatments on Sitophilus zeamais infestation and maize seed quality. Online Undergraduate and Postgraduate Theses, Federal University of Agriculture, Abeokuta. Internet: http://journal.unaab.edu.ng/index.php/theses/thesis/view/4573/ (Accessed 25.06.2016)

ACES [Alabama Cooperative Extension System] 2017. Stored Grains: Insect Control Recommendations for 2017. Alabama A\&M and Auburn Universities. Internet: http://www.aces. edu/pubs/docs/I/IPM-0330/IPM-0330.pdf/ (Accessed 5.08.2017)

Agarwal A., Lal S., GuPTA K.C. 1988. Natural products as protectants of pulses against the pulse beetles. Bulletin of Grain Technology 26(2): 154-164.

Ahuchaogu C.E., Oлiako F.O. 2015. Comparative study of the toxic effects of Jatropha curcas L. extracts and Actellic 25 E.C ${ }^{\circledR}$ on Callosobruchus maculatus (FABRICIUS) (Coleoptera: Chrysomelidae: Bruchinae) in stored cowpea. FUTA Journal of Research in Sciences 2015(2): 231-242.

Akami M., Chakira H., Andongma A.A., Khaeso K., Gbaye O.A., Nicolas N.Y., Nukenine E-N., NIU C-Y. 2017. Essential oil optimizes the susceptibility of Callosobruchus maculatus and enhances the nutritional qualities of stored cowpea Vigna unguiculata. Royal Society open science 4(8): 170692.

AKINKUROLERE R.O. 2012. Comparative effects of three plant powders and pirimiphos-Methyl against the infestation of Callosobruchus maculatus (F.) (Coleoptera: Bruchidae) in cowpea seeds. SOAJ of Entomological Studies 1(2): 108-117.

Akinkurolere R.O., Adedire C.O., Odeyemi O.O. 2006. Laboratory evaluation of the toxic properties of forest anchomanes, Anchomanes difformis against pulse beetle Callosobruchus maculatus (Coleoptera: Bruchidae). Insect Science 13(1): 25-29.

Alexandratos N., Bruinsma J . 2012. World agriculture towards 2030/2050: the 2012 Revision. ESA Working Paper No. 12-03. FAO, Rome.

Amerine M.A., PAngborn R.M., Roessler E.B. 1965. Principles of Sensory Evaluation of Food. Academic Press, New York, USA. 
AOAC [Association of Official Analytical Chemists] 2005. Official Methods of Analysis (OMA) of the Association of Official Chemists, $18^{\text {th }}$ Edition. Association of Official Analytical Chemists, Washington DC.

Ashamo M.O, Odeyemi O.O. 2001. Protection of maize against Sitophilus zeamais Motsch. using seed extracts from some indigenous plants. Journal of Plant Diseases and Protection 108(3): $321-326$.

Asogwa E.U., Dongo L.N. 2009. Problems associated with pesticide usage and application in Nigerian cocoa production: A review. African Journal of Agricultural Research, 4(8): 675-683.

Ayoola S.O., AJAni E.K. 2008. Histopathological Effects of Cypermethrin on Juvenile African Catfish (Clarias gariepinus). World Journal of Biological Research 2(2):1-14.

BeCK C.W., Blumer L.S. 2014. A Handbook on Bean Beetles, Callosobruchus maculatus. Developing Bean Beetles as a Model System for Undergraduate Laboratories. National Science Foundation, Virginia, USA. Internet: http://www.beanbeetles.org/handbook/handbook.pdf (Accessed 12.02.2015)

Besong E.E., Balogun M.E., Duobissie S.F.A., Mbamalu O.S., Obimma J.N. 2016. A Review of Piper guineense (African Black Pepper). International Journal of Pharmacy and Pharmaceutical Research 6(1): 368-384.

Boeke J.B., Kossou D.K., Huis A.V., Vanloon J.J.A., Dicke M. 2004. Field trials with plant products to protect stored cowpea against insect damage. International Journal of Pest Management; 50(1): 1-9.

CASwell G.H. 1980. A review of work done in the Entomological Section of the Institute for Agricultural Research on pests of stored grain. Samaru Miscellaneous Paper 13: 1-12.

ČerñÁková M., Kurucová M., Fuchsová D. 1992. Effect of the insecticide actellic on soil microorganisms and their activity. Folia Microbiologica 37(3): 219-222.

DANKWA J.A. 1998. Efficacy of four protectants applied to stored Bambara groundnut against infestation by Callosobruchus maculatus (FAB.). M. Phil. Thesis, University of Ghana. Internet: http://ugspace.ug.edu.gh:8080/xmlui/handle/123456789/7349 (Accessed 8.05.2017)

Dasbak M.A., Echezona B.C., Asiegbu J. E. 2009. Post-harvest bruchid richness and residual activity of pirimiphos-methyl on Callosobruchus maculatus F. infested pigeon pea (Cajanus cajan L. MiLlSP.) in storage. African Journal of Biotechnology 8(2): 311-315.

Dayan F.E., Cantrell C.L., Duke S.O. 2009. Natural products in crop protection. Bioorganic and Medicinal Chemistry 17(12): 4022-4034.

DiKe M.C., Mshelia G.B. 1997. Laboratory assessment of the efficacy of Eucalyptus leaf and stem powders in the control of Callosobruchus maculatus (F.) on stored cowpea. Samaru Journal of Agricultural Research 14: 11-18.

Echo I.A., Osuagwu A.N., Agbor R.B., Okpako E.C., Ekanem B.E. 2012. Phytochemical composition of Aframomun melegueta and Piper guineense seeds. World Journal of Applied Environmental Chemistry 2(1): :17-21.

ENV/JM/MONO. 2015. Environment Directorate, Joint Meeting of the Chemicals Committee and the Working Party on Chemicals, Pesticides and Biotechnology. Consensus Document on the Biology of Cowpea (Vigna unguiculata (L.) WALP.). Series on Harmonisation of Regulatory Oversight in Biotechnology, No. 60. Environment Directorate Organisation for Economic Cooperation and 
Development, Paris, France. Internet: http://www.oecd.org/officialdocuments/publicdisplay documentpdf $/$ ?cote $=$ env/jm/mono(2015)48\&doclanguage=en $($ Accessed 03.06.2016)

Fakayode B.S., OMOtesho A.O., Adebayo T.Z. 2014. An economic survey of cowpea (Vigna unguiculata) storage practices in Kwara State, Nigeria. Bangladesh Journal of Agricultural Research 39(1): 47-57.

FAtoPe M.O., Mann A., TAKeda Y. 1995. Cowpea weevil bioassay: A simple prescreen for plants with grain protectant effects. International Journal of Pest Management 41(2): 44-86.

Fuseini G.I., Ebsworth P., Jones S., KNight D. 2011. The efficacy of Actellic 50 EC, Pirimiphosmethyl, for indoor residual spraying in Ahafo, Ghana: area of high vector resistance to pyrethroids and organochlorines. Journal of Medical Entomology 48(2): 437-40.

Gbaye O.A., Oyeniyi E.A., Fatore T.D. 2015. Tolerance to Piper guineense (Schum and Thonn) powder among Ekiti State populations of Callosobruchus maculatus (FAB.). FUTA Journal of Research in Sciences 2015(2): 273-280

Godfray H C.J., Beddington J.R., Crute I.R., Haddad L., Lawrence D., Muir J.F., Pretty J., Robinson S., Thomas S.M., Toulmin C. 2010. Food security: The challenge of feeding 9 billion people. Science 327(5967): 812-818.

GrZywaCZ D., LEAVETT R. 2012. Biopesticides and their role in modern pest management in West Africa. Natural Research Institute/University of Greenwich Collaboration; 2012. Internet: http://www.nri.org/news/archive/2012/20120413-biopesticides.htm (Accessed 7.08.2016)

HALSTEAD D.G.H. 1963. External sex differences in stored products Coleoptera. Bulletin of Entomological Research 54(1): 199-134.

Ibekwe H.N., Ogbu J.U., Uwalaka O.A., Ngbede S.O., OnYegbule U.N. 2014. Efficacy of plant derived insecticides for control of insect pests of garden egg (Solanum spp.) in Southeastern Nigeria. International Journal of Scientific and Technology Research 3(8): 371-376.

IDACHABA F.S., OLAYIDE S.O. 1976. The economics of pesticide use in Nigerian Agriculture. [in: F.S IDACHABA. (ed.). A report of a study commissioned by the Federal Department of Agriculture, Lagos, Nigeria. Federal Department of Agriculture, Lagos, 9-10.

IdRis A., RASAKi K., Folake T., HaKeem B. 2013. Analysis of pesticide use in cocoa production in Obafemi Owode Local Government Area of Ogun State, Nigeria. Journal of Biology, Agriculture and Healthcare 3(6): 1-9.

IITA [International Institute of Tropical Agriculture] 2012. Cowpea (Vigna unguiculata). International Institute of Tropical Agriculture, Ibadan. Internet: http://www.iita.org/cowpea (Accessed 11.07.2017)

ISMAN M.B. 2006. Botanical insecticides, deterrents, and repellents in modern agriculture and an increasingly regulated world. Annual Review of Entomology 51: 45-66.

Ivbijaro M.F., Agbaje M. 1986. Insecticidal activities of Piper guineense Schum. and ThonN and Capsicum species on the cowpea bruchid, Callosobruchus maculatus F. International Journal of Tropical Insect Science 7(4): 521-524.

IVBIJARO M.F.1990. The efficacy of seed oils of Azadirachta indica A. Juss and Piper guineense SCHum and THONN on the control of Callosobruchus maculatus (F.). International Journal of Tropical Insect Science 11(2): 149-152. 
Juliani H.R., Koroch A.R., Giordano L., Amekuse L., Koffa S.J., Asante-Dartey S.E., Simon J.E. 2013. Piper guineense (Piperaceae): Chemistry, traditional uses and functional properties of West African black pepper. [in:] H.R. Juliani, J.E. SimON, C.-T. Ho (eds.). African Natural Plant Products. Volume II: Discoveries and Challenges in Chemistry, Health and Nutrition. ACS Symposium Series, Vol. 1127. American Chemical Society, Washington, DC, 33-48.

Kergoat G.J., Silvain J.F., Delobel A., Tuda M., Anton K.W. 2007. Defining the limits of taxonomic conservatism in host-plant use for phytophagous insects: Molecular systematics and evolution of host-plant associations in the seed-beetle genus Bruchus linnaeus (Coleoptera: Chrysomelidae: Bruchinae). Molecular Phylogenetics and Evolution 43(1): 251-269.

LALE N.E.S. 1992. A Laboratory study of the comparative toxicity of product from three spices to the maize weevil. Post-harvest Biology and Technology 2(1): 61-64.

LARMOND E. 1977. Laboratory Methods for Sensory evaluation of food. Agriculture Canada, Research Branch, Ottawa.

Mollins J. 2016. Can sub-Saharan Africa meet its future cereal food requirement? International Maize and Wheat Improvement Center (CIMMYT). Internet: http://www.cimmyt.org/can-subsaharan-africa-meet-its-future-food-requirement/ (Accessed 14.082017)

Mulungu L.S., Luwondo E.N., Reuben S.O.W.M, Misangu R.N. 2007. Effectiveness of local botanicals as protectants of stored beans (Phaseolus vulgaris L.) against bean bruchid (Zabrotes subfasciatus Вон.) (Genera: Zabrotes. Family: Bruchidae). Journal of Entomology 4(3): 210-217.

Nwankwo C.S., Ebenezer I.A., IkPeama A.I., Asuzu F.O. 2014. The Nutritional and anti-nutritional values of two culinary herbs - Uziza Leaf (Piper guineense) and Scent Leaf (Ocimum gratissium) popularly used in Nigeria. International Journal of Science and Engineering Research 5(12): $1160-1163$.

Ogendo J.O., Deng A.L., Belmain S.R., Walker D.J., Musandu A.A.O. 2004. Effect of insecticidal plant materials, Lantana camara L. and Tephrosia vogelii HoOK, on the quality parameters of stored maize grains. The Journal of Food Technology in Africa 9(1): 29-35.

Ogunwolu E.O, Odunlami A.T. 1996. Suppression of seed bruchid (Callosobruchus maculatus F.) development and damage on cowpea (Vigna unguiculata (L.) WALP.) with Zanthoxylum zanthoxyloides (LAM.) WATERM. (Rutaceae) root bark powder when compared to neem seed powder and pirimiphos-methyl. Crop Protection 15(7): 603-607.

Ojiako F.O., Agu C. M., Ahuchaogu C. E. 2013. Potentiality of Moringa oleifera Lam. extracts in the control of some field - store insect pests of cowpea. International Journal of Agronomy and Plant Production 4(S): 3537-3542.

Okogun J.I., Sondengan B.L., Kimbu S.F. 1977. New amides from the extracts of Piper guineense. Phytochemistry 16(8): 1295.

Окоnкwо E.U., ОкочE W.I. 1996. The efficacy of four seed powders and the essential oils as protectants of cowpea and maize grains against infestation by Callosobruchus maculatus (FABRICUS) (Coleoptera: Bruchidae) and Sitophilus zeamais (MOTSCHULSKY) (Coleoptera: Curculionidae) in Nigeria. International Journal of Pest Management 42(3): 143-146.

Окоnкwо Е.U., Окоче W.I. 2002: Effect of Plant materials on damage and germination of cowpea seeds stored on small farms. Nigerian Journal of Entomology 19: 90-98.

OкоYе E.I, Ebeledike A.O. 2013. Phytochemical constituents of Piper guineense (UzIZA) and their health implications on some microorganisms. Global Research Journal of Science 2(2): 42-46. 
OKunlola A.I., AKINRINNOla O. 2014. Effectiveness of botanical formulations in vegetable production and bio-diversity preservation in Ondo State, Nigeria. Journal of Horticulture and Forestry 6(1): 6-13.

Okunlola A.I., OfuYa T.I., AladeSANwa R.D. 2008. Efficacy of plant extracts on major insect pests of selected leaf vegetables in south-western Nigeria. Nigeria Agricultural Journal 3(3), 181-184.

ONu I., Aliyu M. 1995. Evaluation of powdered fruits of four peppers (Capsicum) spp. for the control of Callosobruchus maculatus (F.) on stored cowpea seed. International Journal of Pest Management 41(3): 143-145.

OpARAeKE A.M., DiKe M.C. 1996. Comparison of Garlic and Lemon grass products in the control of Callosobruchus maculatus (F.) (Coleoptera: Bruchidae) in stored cowpea grains. Nigerian Journal of Entomology 13: 73-80.

Oparaeke A.M., Dike M.C. 2005. Monodora myristica (GAERTN.) DunAl (Myristicaceae) and Allium cepa L. (Liliaceae) as protectants against cowpea seed bruchid, Callosobruchus maculatus (F.) infesting stored cowpea seeds. Nigerian Journal of Entomology 22: 84-92.

Oparaeke A.M., Dike M.C., ONU I. 1998. Evaluation of seed and leaf powders of Neem (Azadirachta indica A. Juss) and Pirimiphos methyl for control of Callosobruchus maculatus (F.) in stored cowpea. [in:] Entomological Society of Nigeria Occasional Publication 31: 237-242.

Oparaeke A.M., Dike M.C., ONU I. 2002. Control of Callosobruchus maculatus (FAB.) on stored cowpea with African Curry (Ocimum gratissimum L.) and African Bush Tea (Hyptis sauveolens PoIT) leaf powders. Nigerian Journal of Entomology 19: 99-108.

OyeniYi E.A., Gbaye O.A., Holloway G.J. 2015. The influence of geographic origin and food type on the susceptibility of Callosobruchus maculatus (FABRICIUS) to Piper guineense (SCHUM and THONN). Journal of Stored Products Research 63: 15-21.

OyewAle R.O., BAmaiYi L.J. 2013. Management of cowpea insect pests. Scholars Academic Journal of Biosciences 1(5): 217-226.

Purseglove J.W., Brown E.G., Robin R.J. 1981. Spices. Longman, New York.

Scott I.M., Jensen H., Nicol R., Lesage L., Bradbury R., Sanchez-Vindas P., Povenda L., Arnason J.T., Philongene B.J.R. 2004. Efficacy of Piper (Piperaceae) extracts for control of common home garden pests. Journal of Economic Entomology 97(4): 1390-1403.

Scott I.M., Jensen H.R., Philogène B.J., Arnason J.T. 2008. A review of Piper spp. (Piperaceae) phytochemistry, insecticidal activity and mode of action. Phytochemistry Reviews 7(1), 65-75.

Shoura Chemicals 2012. Diseases and pests of Okra (Abelmoschus esculentus). Internet: http: //www.shouragroup.com/vOkrae.htm. (Accessed 12.08.2016)

TALUKDER F.A., HowSE P.E. 2000. Isolation of secondary plant compounds from Aphanamixis polystachya as feeding deterrents against adults Tribolium castaneum (Coleoptera: Tenebrionidae). Journal of Stored Product Research 107(5): 395-402.

TAYLOR T.A. 1975. Motivation and method in ensuring protection of tropical produce from grower to his market. [in:] E.U. Brady, J.H. Brower, P.E. HunTER, E.G. JAY, P.T.M. LuM, H.O. LuND, M.A. Mullen, R. DAvis (eds.). Proceedings of the 1st International Working Conference on Stored-Product Entomology, 7-11 October 1974, Savannah, Georgia, USA. Savannah, Georgia, USA, 11-17. 
Tiroesele B., Thomas K., Seketeme S. 2015. Control of cowpea weevil, Callosobruchus maculatus (F.) (Coleoptera: Bruchidae), using natural plant products. Insects 6(1): 77-84.

UkPai O.M., IBEDIUnGHa B. N., EhISIANYA.C.N. 2017. Potential of seed dusts of Jatropha curcas L., Thevetia peruviana (PERS.) and Piper guineense SCHUMACH. against the maize weevil, Sitophilus zeamais (Motschulsky, 1855) Coleoptera: Curculionidae) in storage of corn grain. Polish Journal of Entomology 86(3): 237-250.

UN DESA [United Nations Department of Economic and Social Affairs] 2015. United Nations Department of Economic and Social Affairs Report. World Population Prospects: The 2015 Revision. Internet: https://esa.un.org/unpd/wpp/publications. (Accessed 5.08.2016)

VAN HuIs A. 1991. Biological methods of bruchid control in the Tropics: A review. International Journal of Tropical Insect Science 12(1-2-3): 87-102.

VerdCourt B. 1970. Studies in the Leguminosae-Papilionoïdeae for the 'Flora of Tropical East Africa' IV. Kew Bulletin 24(3): 507-569.

WHO [World Health Organization] 2004. WHO Specifications and Evaluations for Public Health Pesticides: Pirimiphos-Methyl (O-2-diethylamino-6-methylpyrimidin-4-yl-O,O-dimethyl phosphorothioate). WHO Pesticide Evaluation Scheme (WHOPES). World Health Organization, Geneva. Internet: http://www.chinaphar.com/167-4083/24/241.pdf. (Accessed 13.06.2016)

YoudeOweI A. 1980. Insects and Nigerians: The Struggle for Existence. An Inaugural Lecture delivered at the University of Ibadan on Thursday, 17 February, 1977. University of Ibadan, Nigeria.

Received: 31 October 2017

Accepted: 3 January 2018 